\title{
Ympäristöjärjestelmien soveltaminen hevostalouteen - EquineLife- hanke
}

\author{
Hanna Virtanen ${ }^{1,2}$, Inkeri Pesonen ${ }^{1}$, Suvi Pakarinen ${ }^{3}$ \\ ${ }^{1)}$ MTT Maa- ja elintarviketalouden tutkimuslaitos, Biotekniikka ja elintarviketutkimus, L- talo, 31600 \\ Jokioinen hanna.virtanen@mtt.fi, inkeri.pesonen@mtt.fi \\ ${ }^{2)}$ Helsingin yliopisto, Soveltavan biologian laitos, Latokartanonkaari 9, 00014 Helsingin yliopisto \\ ${ }^{3)}$ Helsingin yliopisto, Bio- ja ympäristötieteiden laitos, Viikinkaari 9, 00014 Helsingin yliopisto, \\ suvi.pakarinen@helsinki.fi
}

\section{Tiivistelmä}

Hevosten lukumäärä on yli kaksinkertaistunut vuodesta 1980. Vuonna 2006 hevosia oli rekisterissä 66 050, kun vastaava luku vuonna 1980 oli 31 484. Talleja Suomessa oli vuonna 2005 arviolta 15000 ja määrän arvioidaan kasvavan entisestään.

Hevostallien lisääntyessä sekä keskittyessä erityisesti kasvukeskusten yhteyteen myös niistä aiheutuvien ympäristöhaittojen merkitys korostuu. Pienilläkin talleilla lannasta aiheutuva ravinne- ja mikrobikuormitus saattaa paikallisesti olla merkittävä vesiensuojelullinen sekä hygieniaongelma. Ratsastus sekä hevosten tarhaaminen aiheuttaa eroosiota, maaston kulumista ja kasvillisuuden tallaantumista sekä tämän myötä maaston vettymistä. Välillisesti hevosenpito aiheuttaa ympäristökuormituksia mm. rehun- ja sähköntuotannon kautta. Ympäristölupa vaaditaan pääsääntöisesti kuitenkin vasta 60 hevosen tallilta. Systemaattiselle ympäristöasioiden hoidolle on siis tarvetta myös kasvavassa hevostaloudessa.

Tätä taustaa vasten Euroopan Unionin LIFE Ympäristö- rahoitusvälineen päärahoittamassa hankkeessa EquineLife - toimintamalli ekologisesti ja eettisesti kestävälle hevosurheilulle sovellettiin ympäristöjärjestelmiä hevostalouteen ja luotiin toimintamalleja hevostalouden ympäristö-, turvallisuus- ja hyvinvointiasioiden kehittämiseksi niin hevosyrityksissä kuin -tapahtumissakin. Toimintamallien pohjana oli Euroopan Unionin asetukseen perustuva EMAS (The Eco-Management and Audit Schme) -ympäristöjärjestelmä. Kahdessa pilot- kohteessa, MTT Hevostaloudessa sekä Ypäjän Hevosopistolla, EMAS- ympäristöjärjestelmä myös rekisteröidään vuonna 2008.

Standardiin perustuvia ympäristöjärjestelmiä on sovellettu Euroopassa muuhun kotieläintalouteen, mutta ei hevostalouteen. Ruotsissa, Ranskassa ja Tanskassa on kokemuksia ISO14001- standardin käytöstä yleisesti maataloudessa. Myös Yhdysvalloissa ISO14001- ympäristöjärjestelmiä on sovellettu siipi-, liha- ja lypsykarjatalouteen. Sen sijaan Australiassa on rakennettu ISO14001järjestelmiä myös hevostalouteen. Kuitenkin hevostalouteen on käytetty itse kehitettyjä ympäristöjärjestelmiä ja -ohjelmia erityisesti Yhdysvalloissa sekä Australiassa ja jonkun verran EurooprapsineLife- hankkeesta saadut kokemukset myötäilevät muualta maailmasta saatuja tuloksia. Niissä hyötyinä nähtiin mm. tilastotiedon kerääminen, hiljaisen tiedon dokumentointi, jätehuollon ja ympäristönsuojelun kehittyminen sekä kustannussäästö- ja imagohyödyt. Järjestelmiä pidettiin kuitenkin aikaavievinä, vaikeaselkoisina, byrokraattisina ja rasitteina päätoiminnolle.

Asiasanat: Hevostalous, ympäristöjärjestelmät, EMAS 


\section{Johdanto}

Ympäristöjärjestelmien soveltaminen hevostalouteen on maailmalla vielä alkutekijöissään ja aiheesta on saatavilla niukasti kirjallisuutta ja tutkimustuloksia. Euroopan tasolla ympäristöjärjestelmiä on sovellettu lähinnä kotieläintalouteen, mutta ei juuri hevostalouteen. Australiassa on toteutettu useita ympäristöjärjestelmähankkeita esimerkiksi lammas- ja hevostaloudessa (Frizenschaf 2007, Huhn ym. 2007). Yhdysvalloissa ympäristöjärjestelmiä on sovellettu siipi-, liha- ja lypsykarjatalouteen, ja myös hevostalouteen on kiinnitetty runsaasti huomiota (Partnerships for livestock...2006). Australiassa hevostalouteen on sovellettu standardipohjaisia järjestelmiä, kun taas Euroopassa ja Yhdysvalloissa itsekehitettyjä, toimialakohtaisia järjestelmiä.

Maailmalla yleisimmin käytössä oleva ympäristöjärjestelmä on ISO 14001 (International Oganization for Standardization). Euroopassa suosiota on saanut myös Euroopan Unionin asetukseen perustuva EMAS (The Eco-Management and Audit Scheme). Kummatkin standardit voidaan soveltaa mihin tahansa organisaatioon, instituutioon tai yritykseen. (Wall ym. 2001.)

EMAS ja ISO 14001 edellyttävät ympäristöohjelman toteuttamista ja ympäristönsuojelun tason jatkuvaa parantamista. EMAS- asetus on hyvin analoginen ISO 14001-standardin kanssa. Suurin ero järjestelmien välillä on EMAS- asetuksessa vaadittu ympäristöraportti eli EMAS- selonteko, joka ei ole pakollinen ISO14001 -standardissa. Molemmat järjestelmät perustuvat siihen vaatimukseen, että yritys tuntee toimintansa aiheuttamat ympäristövaikutukset, noudattaa ympäristölainsäädäntöä, tunnistaa sidosryhmien vaatimukset $\mathrm{ja}$ asettavat itse tämän perusteella ympäristönsuojelulliset tavoitteet omalle toiminnalleen. Järjestelmää on myös säännöllisesti auditoidava. Yritysten tulee myös itse valita keinot, joilla he pyrkivät saavuttamaan asetetut tavoitteet aikataulunsa mukaisesti. Päämääränä on ympäristönsuojelun tason jatkuva parantaminen.

Ympäristöjärjestelmän käyttö ei automaattisesti tarkoita, että yrityksen toiminta olisi ympäristöystävällistä. Järjestelmä indikoi yrityksessä sitä, että ympäristöasiat on otettu huomioon, ja että toiminnan harjoittaja on sitoutunut jatkuvaan ympäristöntilan parantamiseen ja ympäristöasioiden huomioonottamiseen. (Wall ym. 2001.)

Tämän artikkelin tavoitteena on tuoda esiin kokemuksia ja näkemyksiä ympäristöjärjestelmien soveltamisesta hevos- ja kotieläintaloudessa maailmalla sekä EquineLife- hankkeessa.

\section{Kokemuksia ympäristöjärjestelmien soveltamisesta hevostaloudessa}

Ympäristöjärjestelmiä on sovellettu eri puolilla maailmaa hevostalouteen vasta aivan viime vuosina. Huomattavasti eniten on sovellettu ISO14001- standardia. Maailmanlaajuisesti erilaisia ympäristöohjelmia ja muita hevosalakohtaisia järjestelmiä on kehitetty, mutta ne toimivat toistaiseksi melko pienessä mittakaavassa. Sovellukset on usein toteutettu EquineLife- hankkeen tapaan erilaisina hankkeina ja projekteina, joita eri maiden maatalouden tutkimuskeskukset ovat pääasiallisesti toteuttahestraliassa hevostalouteen suunnatussa ympäristöjärjestelmien pilottihankkeessa luotiin oma ympäristöjärjestelmä hevostiloille. Tässä kolmivuotisessa hankkeessa pilottitalleina toimivat hyvin erilaiset tallit erilaisista lähtökohdista. Ympäristöjärjestelmän päätavoitteena oli maaperän ja vesistöjen suojelu. Järjestelmä kattoi lisäksi veden- ja sähkönkulutuksen, luonnon monimuotoisuuden suojelun, tuholaiseläinten ja rikkakasvien torjunnan, jätteiden lajittelun, paloturvallisuuden, kemikaalien käytön sekä ilmanlaadun ja melun. Pilottitalleille järjestettiin työpajoja ja kenttäpäiviä ja niitä ohjasi tutkijoista ja hevosalan ammattilaisista koostuva paneeli. Jo hankkeen alkuvaiheessa todettiin, että selkeät ja yksinkertaiset ohjeet ympäristöhaittojen vähentämiseksi ovat tarpeen ja ne tulisi olla tilakohtaisesti räätälöidyt. (Frizenschaf 2007.)

Ympäristöjärjestelmä toteutettiin hevostiloilla vaiheittain. Ensimmäisessä vaiheessa tavoitteena oli kehittää ympäristöjärjestelmän prototyyppi hevostiloille. Tämän vaiheen riskinarviointi osoittautui hankalaksi, etenkin niiden hevostenomistajien keskuudessa, joilla hevosten pito perustui harrastukseen. He olivat lähinnä kiinnostuneita hevosen hyvinvoinnista ja innostus ympäristöasioihin oli vähäistä. Pilottiryhmältä puuttui myös tietoa siitä, miten haastavissa luonnonoloissa harjoitettu hevostalous voi aiheuttaa negatiivisia ympäristövaikutuksia, joten aiheesta tehtiin ryhmälle opaskirja. Seuraavassa vaiheessa hevostiloille tehtiin toimintasuunnitelma (Action Planner), joka keskittyi ympäristöriskien arviointiin ja käyttöönoton aikatauluun. Itsearvioinnin kautta pyrittiin käyttäjät saamaan ymmärtämään toiminnasta aiheutuvat ympäristöhaitat ja tekemään parannuksia toimintasuunnitelman avulla. (Frizenschaf 2007.) 
Hankkeen päätyttyä yli $80 \%$ osallistujista oli sitä mieltä, että hankkeen avulla oli saavutettu merkittäviä parannuksia hevostiloilla. Osallistujat olivat myös lisänneet ympäristötietouttaan ja harkitsivat ympäristöjärjestelmän käyttöönottoa hankkeen päätyttyä. (Frizenschaf 2007.)

Hevostaloudelle on kehitetty omia toimialakohtaisia ympäristöohjelmia myös Iso-Britanniassa ja Yhdysvalloissa (British Horse...2005, Blickle 2001). Etelä-Afrikassa on kehitetty Table Mountainin kansallispuistoon ympäristöohjelma, jossa tarkastellaan kansallispuistoissa tapahtuvaa ratsastustoimintaa (The Cape Peninsula... 2004). Kaikissa näissä ympäristöohjelmissa on vähintäänkin pyritty vähentämään maaston kulumista ja ravinnevalumia. Etelä-Afrikassa otettiin huomioon myös alueen asukkaat ratsastusvaelluksia järjestettäessä.

Yhdysvaltojen Connecticutissa on ollut käynnissä HEAP- ohjelma (The Horse Environmental Awarness Program). Se on valtion, paikallisten järjestöjen ja hevostenomistajien yhteinen ohjelma, jolla pyritään parantamaan ympäristön tilaa. Connecticutin osavaltiossa on Yhdysvaltain suurin hevostiheys, jopa neljä hevosta neliökilometriä kohti, eli yhteensä noin 50000 hevosta. Yhtenä osana HEAP- ohjelmaa on ollut Horse Farms of Environmental Distinction- projekti. Sen lähtökohtana on ollut hevosenomistajien vapaaehtoinen osallistuminen ja palkitseminen ympäristönsuojelutoimenpiteistä. (Nadeau \& Meader 2003.) HEAP- ohjelma on julkaissut useita selvityksiä ja ohjeita hevosenomistajille.

\section{Käsityksiä ympäristöjärjestelmistä kotieläintaloudessa}

Kuten edellä on todettu, Australiassa hevostalouden pilottihankkeen päättyessä valtaosa talliyrittäjistä piti hankkeen avulla saavutettuja parannuksia merkittävinä, ympäristöjärjestelmien vaikeaselkoisuudesta huolimatta (Frizenschaf 2007).

Seymour (2007) selvitti niin ikään Australiassa eri maatalouden harjoittajien käsityksiä ympäristöjärjestelmistä. Tutkimuksessa haastateltiin eri maatalouden aloja harjoittavia henkilöitä, jotka olivat keskimääräistä enemmän ympäristötietoisia. Tutkimuksessa kävi ilmi, että ympäristöjärjestelmiin ei liitytä sen pelon varjolla, että ne ovat byrokraattisia ja niiden pelätään itsemääräämisoikeuden häviämistä. Maatalouden harjoittajat uskoivat ympäristöjärjestelmien olevan aikaa vieviä ja velvoittavan ylimääräiseen työhön. Tutkimuksen mukaan tärkein syy liittyä oli yhteisön ja yleisen hyvän vuoksi, eikä esimerkiksi taloudelliset syyt. Myös Carruthers (2005) painottaa ympäristöjärjestelmiin kohdistuvaa skeptisyyttä ja epäilyjä saavutetuista hyödyistä.

Oikeanlaisella kannustuksella uskotaankin olevan suuri vaikutus ympäristöjärjestelmien käyttöönottoon (Bergström ym. 2002, Huhn ym. 2007.) Australiassa kannustimina on käytetty mm. verohelpotuksia ja lisenssimaksuhelpotuksia (Carruthers 2005). Myös Suomessa toimialasta riippumatta EMAS- rekisterissä oleva yritys saa ympäristölupamaksuista 35\% alennuksen. Hidasteena ympäristöjärjestelmien laajamittaisemmalle käytölle nähdään olevan standardin vaikea ymmärtäminen. Jotta päästään standardinmukaiseen toimintaan, tarvitaan paljon koulutusta ja perehdytystä (Grolleau 2000, Bergström ym. 2002).

Australian kokemuksien mukaan, asteittainen eteneminen kohti ympäristöjärjestelmän sertifioimista on kannattavaa. Ympäristöjärjestelmän käyttöönotto voidaan aloittaa itse tehdystä ympäristökatselmuksesta. Ympäristökatselmus ei varsinaisesti kuulu ISO 14001 standardiin, mutta se on koettu hyväksi menetelmäksi muissakin tutkimuksissa. EMAS- järjestelmässä ympäristökatselmus on pakollinen. Ympäristöasioiden itsearvioinnin avulla on saavutettu hyvä lähtökohta, kun toiminnan harjoittaja alkaa kehittää omaa ympäristöhallintaansa. (Carruthers \& Tinning 2003, Huhn ym. 2007, Seymour 2007).

Australian lammastalouteen sovelletussa ympäristöjärjestelmässä havaittiin, että suuremman maatilan oli helpompi mieltää ympäristöjärjestelmä osaksi toimintaansa (Huhn ym. 2007). Ympäristöjärjestelmän toteuttaminen oli jaettu neljään eri vaiheeseen, joista ensimmäisessä tehtiin katselmointia. Lammaskasvattajista suurin osa tähtäsi toiseen tasoon, jossa tehtiin ympäristösuunnitelma omalle tilalle. Tasoon kuului lisäksi mm. riskinarviontia. Tasoon kolme ja neljä ylittivät vain muutama pilottikohde. Myös tässä tutkimuksessa todettiin, että kannustimien ja tuen vaikutus ympäristöjärjestelmän läpiviemiseen ovat avainasemassa, mutta myös etukäteen hankitulla ympäristötietoisuudella oli merkittävä vaikutus ympäristöjärjestelmän omaksumiseen (Huhn ym. 2007).ISO 14001 sovelluksissa on keskitytty tiukasti ympäristönsuojelullisiin toimintoihin kotieläintaloudessa. Carruthersin (2005) loppuraportissa tulee ilmi, että tulevaisuudessa kaivataan eläinten hy- 
vinvoinnin huomioimista ympäristönsuojeluseikkojen ohella. Australialaisissa ympäristöhankkeissa on kiinnitetty huomiota myös eläinten hyvinvointiin ympäristöjärjestelmien yhteydessä. Myös EquineLife- hankkeessa hevosten hyvinvointi on järjestelmän keskiössä.

\section{EquineLife- hankkeen toteutus}

Vuoden 2004 lopulla alkanut EquineLife- hankkeessa haettiin toimintamalleja kestävälle hevostaloudelle sekä testattiin erilaisia teknisiä ratkaisuja, kuten haketarhoja sekä sääsuojia. Lisäksi hankkeessa etsittiin ratkaisuja hevostoimijoiden yhteistyöhön ja konfliktitilanteisiin sekä tehtiin hevospolitiikkavertailu Suomen, Ruotsin ja Alankomaiden kesken. Hankkeen päätoteuttajat olivat MTT, Suomen Hippos ry., Suomen Ratsastajainliitto ry., Forssan Seudun Hippos ry., Ypäjän Hevosopisto sekä Agropolis Oy. Kaikista organisaatioista oli edustajia itse projektityössä sekä lisäksi hankkeen ohjausryhmässä.

Hankkeen alussa tehtiin kysely noin 80 tallille, jotta päästiin selville laajemmin suomalaisten tallien ympäristö-, turvallisuus- ja hyvinvointitilanteesta. Lisäksi haastateltiin hevostapahtumien järjestäjiä keskeisten ympäristö-, turvallisuus- ja hyvinvointiasioiden esiintuomiseksi tapahtumissa.

Kuten Frizenschaf (2007) raportoi Australiasta, myös EquineLife- hankkeessa nähtiin välttämättömäksi, että talleilla ja tapahtumissa arvioidaan ensin itse omat ympäristöasioiden nykytila, eli tehdään ns. alustava ympäristökatselmus. Katselmus haluttiin tehdä helpoksi, joten tarkoitusta varten laadittiin erilliset kysymyskehikot. Kysymyskehikoissa haluttiin ensisijaisesti tuoda esille lainsäädännön vaatimukset, koska ympäristölainsäädännön noudattaminen on keskeinen osa ympäristöjärjestelmiä. Lainsäädännön lisäksi kysymyskehikoihin sisällytettiin lainsäädännön sekä ympäristöjärjestelmän suosituksia. Ympäristökatselmuksen perusteella tallit voidaan jakaa kolmeen luokkaan: 1. tallit, jotka eivät noudata kaikilta osin lainsäädäntöä, 2. tallit, jotka täyttävät lainsäädännön vaatimukset sekä 3. huipputallit, jotka ylittävät lainsäädännön vaatimukset. Jatkuvan parantamisen periaatteen mukaisesti tallit voivat ympäristöohjelmaa noudattamalla ja ympäristönsuojelun tasoaan parantamalla nousta ns. huipputalliksi. Myös hevostapahtumien järjestäjille

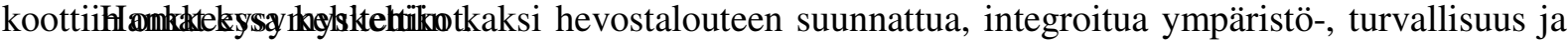
hevosen hyvinvointijärjestelmää. Toinen järjestelmistä suunnattiin talleille ja toinen hevostapahtumien järjestäjille. Järjestelmiä kehitettiin testaten niitä samalla erilaisissa ympäristöissä. Hevostapahtumista pilottikohteina olivat Forssan Kuninkuusravit 2006 sekä esteratsastuskisa XXXIV Finnderby Ypäjällä. Pilottalleina olivat kolme tallia Hämeen alueella. Lisäksi EMAS- ympäristöjärjestelmä rakennettiin Hevosopisto Oy:ssä ja MTT Hevostaloudessa, joissa järjestelmä myös rekisteröidään vuoden 2008 aikana.

EquineLife- hankkeen keskeisenä tuotoksena julkaistaan talliyrittäjille opas, joka osaltaan helpottaa ympäristöjärjestelmän rakentamista talleille. Edellä esitetyt kysymyspatteristot on kerätty oppaaseen niitä tukevan tekstin ja esimerkkien kanssa. Opas toimii pohjatyönä mahdolliselle hevosalan keskusjärjestöjen (Suomen Hippos ry. ja Suomen Ratsastajain Liitto SRL) lanseeraamalle omalle ympäristöjärjestelmälle tulevaisuudessa. Myös hevostapahtumien järjestäjille julkaistaan opas systemaattisen ympäristöhallinnan ja ympäristönsuojelun tason sekä turvallisuuden ja hevosten hyvinvoinnin parantamiseksi.

\section{EquineLife- hankkeen kokemukset ympäristöjärjestelmistä hevostaloudessa}

Hankkeesta saatujen kokemusten mukaan organisaatioiden ja tapahtumienjärjestäjien oma kiinnostus, sitoutuminen ja resurssien varaaminen on keskeistä ympäristöasioiden eteenpäin viemisessä. Sekä tapahtumissa että yrityksissä kiire leimaa työtä ja ympäristöasioiden sisällyttäminen osaksi toimintaa nähdään ylimääräisenä taakkana. Kaikissa pilot- kohteissa ympäristöasioiden jalkauttaminen nähtiin aluksi vaikeana ja siitä tulevat hyödyt vähäisinä. Hevostapahtumissa oman leimansa tuo toiminnan keskittyminen muutamaan päivään, vastuiden pitkälle viety delegointi sekä toiminnan pyörittäminen pitkälti vapaaehtoisvoimin. Lisäksi hevostoimijoiden kiinnostus kohdistuu lähinnä hevosen hyvinvointiin, jonka varjoon sekä turvallisuus- että ympäristöasiat jäävät.

Ympäristöjärjestelmää rakennettaessa nousi esiin etenkin organisaatioiden ympäristövastuuhenkilöille järjestelmän positiiviset puolet. Joulukuussa 2007 tehtiin internet- kysely EMAS- järjestelmän vaikutuksista Maa- ja elintarviketalouden tutkimuskeskuksen Ypäjän toimipisteessä sekä Hevosopisto Oy:llä. Kysely lähetettiin kyseisten organisaatioiden 24:lle toimihenkilölle ja johdon edustajalle. Kyselyyn vastasi 13 henkilöä. Kyselyn perustella järjestelmän hyötyinä nähtiin mm. suullisten ohjeiden ja 
muun hiljaisen tiedon dokumentointi, työohjeiden täsmentyminen, erilaisten käytäntöjen perusteellinen läpikäynti ja tarkastelu, vastuiden selkeytyminen, jätehuollon ja ympäristönsuojelun kehittyminen, 'herääminen' ympäristöasioihin sekä ympäristöjärjestelmän kustannussäästö- ja imagohyödyt. Lisäksi ympäristöjärjestelmää pidettiin hyvänä pohjana laatujärjestelmän rakentamiseen. Järjestelmän haittoina nähtiin suuri työmäärä ( 9 vastaajaa) ja järjestelmän byrokraattisuus ja vaikea termistö (4 vastaajaa). Kuitenkin 13 vastaajasta 11 suosittelisi ympäristöjärjestelmän käyttöönottoa muille vastaaville organisaatioille.

\section{Johtopäätökset}

Hevostalouteen räätälöidyltä ympäristöjärjestelmältä vaaditaan kaikkien esimerkkimaiden mukaan selkeitä ohjeita ja helposti saatavilla olevaa tietoa (Bergström ym 2002, Partnership for Livestock... 2006, Frizenschaf 2007). Lisäksi ympäristöjärjestelmä pitää pystyä räätälöimään toimiala- ja tilakohtaisesti, jotta se olisi mahdollisimman tehokas. Bergström ym. (2002) mukaan menestyksekäs ympäristöjärjestelmien käyttöönotto edellyttää, että toimintaa osataan tarkastella kokonaisvaltaisesti, ympäristönsuojelullisesta, taloudellisesta ja sosio-kulttuurisesta näkökulmasta.

Myös EquineLife- hankkeessa todettiin, että hevosyrityksissä tarvitaan runsaasti ohjeita, opastusta ja asiantuntija-apua ympäristöjärjestelmän rakentamiseen. Erityisesti pienehköjen tallien on vaikeaa mieltää ympäristöjärjestelmää käsitteenä ja kokonaisuutena. Suurin osa talleista perustuu harrastukseen, jossa liikkeenjohdollinen yrittäjyysnäkökulma ei välttämättä ole keskiössä. Ympäristöjärjestelmien (EMAS ja ISO 14001) soveltaminen edellyttää koko toiminnan systemaattista tarkastelua ja resurssit tähän ovat usein vähäiset.

Hevostalouden intressit ympäristöjärjestelmiä kohtaan liittyvät enemmän hevosen hyvinvoinnin taustalla oleviin ympäristönäkökohtiin. Hyvä ympäristön tila on kuitenkin myös edellytys terveille ja hyvinvoiville eläimille, joten ristiriitaa näiden kahden asian välillä ei ole. Ympäristönsuojelun yhdistäminen hevosen hyvinvointiin on keskeinen tekijä hevostaloudessa, joka pitää ymmärtää myös ympäristöjärjestelmiä rakennettaessa ja kehitettäessä.

Suomalaisen hevostalouden kasvun edellytys on, että ympäristöasiat alalla hoidetaan esimerkillisesti. Hevosalan tulee itse toimia asian hyväksi. Toimialakohtainen ympäristöjärjestelmä on varsinkin isoille talliyrityksille hyvä, joskin työläs apuväline tähän tarkoitukseen. Toimivan järjestelmän rakentaminen edellyttää tallinpitäjältä kiinnostusta ja osaamista sekä runsaasti asiantuntijatukea.

\section{Lähteet}

Bergström, M., Hellqvist, L. ja Ljung, M. 2002. Farm certification: implementing and using quality and environmental management systems in Swedish agriculture. Adding value through environmental marketing: opportunities for food producers and retailers. Proceedings of the Conference, Madison, Wisconsin, USA, 6-7 December 1999. 2000: 120-132. Dokumentti saatavissa myös internetistä osoitteesta: http://www.iatp.org/labels/envcommodities/appendixII-b.html\#hellqvist

Blickle, A., R. 2001. Healthy Horses Clean Water. A Guide to Environmentally Friendly Horsekeeping. Horses $\begin{array}{llllll}\text { for } & \text { Clean } & \text { Water. } & 76 & \text { s. } & \text { Pdf-dokumentti }\end{array}$ http://www.psat.wa.gov/Publications/HORSE_MAN.pdf

British Horse Industry Confederation. 2005. Strategy for the horse industry in England and Wales. Department for Environment, Food and Rural Affairs. 108 s. Pdf-dokumentti saatavissa internetosoitteesta:

Carruthers, G. 2005. Adoption of environmental management systems in agriculture: an analysis of 40 case studies. A report for the Rural Industries Research and Development Corporation. Publication number 05/032. 178 s. Saatavissa internetosoitteesta: http://www.rirdc.gov.au/reports/EMSCaseStudies/contents.pdf

Carruthers, G. ja Tinning, G. 2003. Where, and how, do monitoring and sustainability indicators fit into environmental management systems? Australian Journal of Experimental Agriculture. 2003. Vol 43. S. 307-323.

The Cape Peninsula Horse Riding Working Group. 2004. Environmental management program for horse riding in the Table Mountain National Park. 29 s. Pdf-dokumentti saatavissa osoitteesta: http://www.sanparks.org/parks/table_mountain/library/EMP_Horses_final.pdf

Frizenschaf, J. 2007. Environmental management on horse properties. A prototype environmental management system for the horse keeping community - implementation, auditing and monitoring. Rural Industries Research 
and Development Corporation Publication No 06/132. 139 s. Pdf-dokumentti saatavissa osoitteesta: http://www.rirdc.gov.au/reports/HOR/06-137.pdf

Grolleau, G. 2000. Environmental management systems (ISO 14001) a promising tool for farms? Adding value through environmental marketing: opportunities for food producers, processors and retailers. Proceedings of the Conference, Madison, Wisconsin, USA. 6.-7. December 1999. 2000; 77-91. Dokumentti saatavissa internetosoitteesta: http://www.iatp.org/labels/envcommodities/appendixII-a.html\#grolleau

Huhn, K. J., Seymour, E. J. ja Ridley, A. M. 2007. Environmental management systems in the Australian lamb industry: challenges and opportunities for family farms. Australian Journal of Experimental Agriculture. No 47. s.294-302.

Nadeau, J. ja Meader, J. 2003. Motivating change in horse owners: the horse farm of environmental distinction program. Journal of Extension. August 2003. Vol 41 No 4. University of Connecticut Cooperative Extension System. Saatavissa osoitteesta: http://www.joe.org/joe/2003august/iw3.shtml

Partnerships for livestock environmental management systems. Experiences of a five-year collaboration of producers, Extension specialists and researchers in the ten states. Final Report. December

Seymour, E. J. 2007. Benefits, threats and getting started with environmental management systems: views of primary producers and catchment managers in Victoria, Australia. Australian Journal of Experimental Agriculture. No. 47. s.303-311.

Wall, E., Weersink, A. ja Swanton, C. 2001. Agriculture and ISO 14000. Food Policy 2001. Vol. 26. No. 1. S. 35-48 